九州大学学術情報リポジトリ

Kyushu University Institutional Repository

DESCRIPTION OF FIRST-INSTAR LARVA OF SYNEZ' A ADAMSI BALY FROM JAPAN, WITH NOTES ON THE SYSTEMATIC POSITION OF SYNETINAE (COLEOPTERA : CHRYSOMELIDAE)

Lee, Jong Eun

https://doi.org/10.5109/2549

出版情報: ESAKIA. 29，pp.77-81，1990-09-30. Entomological Laboratory，Faculty of Agriculture， Kyushu University

バージョン:

権利関係 : 


\title{
DESCRIPTION OF FIRST-INSTAR LARVA OF SYNETA ADAMSI BALY FROM JAPAN, WITH NOTES ON THE SYSTEMATIC POSITION OF SYNETINAE (COLEOPTERA : CHRYSOMELIDAE)*
}

\author{
JONG EUN LEE \\ Entomological Laboratory, Faculty of Agriculture, Kyushu University, Fukuoka 812, Japan
}

\begin{abstract}
The first-instar larva of Syneta adamsi Baly is described and illustrated for the first time from Japan, and the systematic position of the subfamily Synetinae is discussed on the larval characters.
\end{abstract}

The genus Syneta is a small group of the subfamily Synetinae distributed in the holarctic region, and two species, S.adamsi Baly and S.brevitibialis Kimoto, are known from Japan.

This paper is aimed to give a detailed description of the first instar larva of Syneta adamsi together with illustrations, and to discuss the systematic position of the Synetinae upon the larval character. The material used in this study was obtained by rearing the adults in the laboratory. The morphological terms are followed principally after LeSage (1982).

\section{Syneta adamsi Baly, first instar larva}

(Figs. 1,2)

Body thick, white, somewhat flattened dorsoventrally. Head and 9th and tenth tergites of abdomen pale brown, mandibles blackish brown, pronotum and legs yellowish.

Head. Hypognathous, slightly sclerotized. Epicranial suture distinct, Y-shaped ; coronal suture about one fourth the length of head ; frontal suture broadly divergent and nearly straight ; endocarina half as long as frontal plate. Stemmata(=ocelli) absent. Epicranium with 5 pairs of dorsal epicranial setae, two pairs of lateral setae, 5 pairs of minute epicranial posterior setae, one pair of ventral setae, 2 pairs of dorsal sensilla, 2 pairs of ventral sensilla and 2 pairs of posterior sensilla. Frons broad triangular, with 4 pairs of setae, of which inner 2 pairs shorter, and with 2 pairs of sensilla. Antenna l-segmented, with a large subconical sensory papilla, with 6 spine-like setae, of which exterior 3 thick at base, and with 2 sensory pores. Clypeus trapezoid, with 3 pairs of setae, of which inner pair on fronto-clypeal suture, and with 1 pair of sensilla. Labrum transverse oval, concolorous with clypeus, with 4 pairs of setae, one pair of median sensilla at base and one pair of lateral sensilla. Epipharynx with 3 pairs of antero-lateral setae and 4 pairs of antero-median setae, the former robust, curved and blunt at apex, the latter shorter and pointed ; median part of epiphar-

* Contribution from the Entomological Laboratory, Faculty of Agriculture, Kyushu University, Fukuoka (Ser. 4, No. 12). 


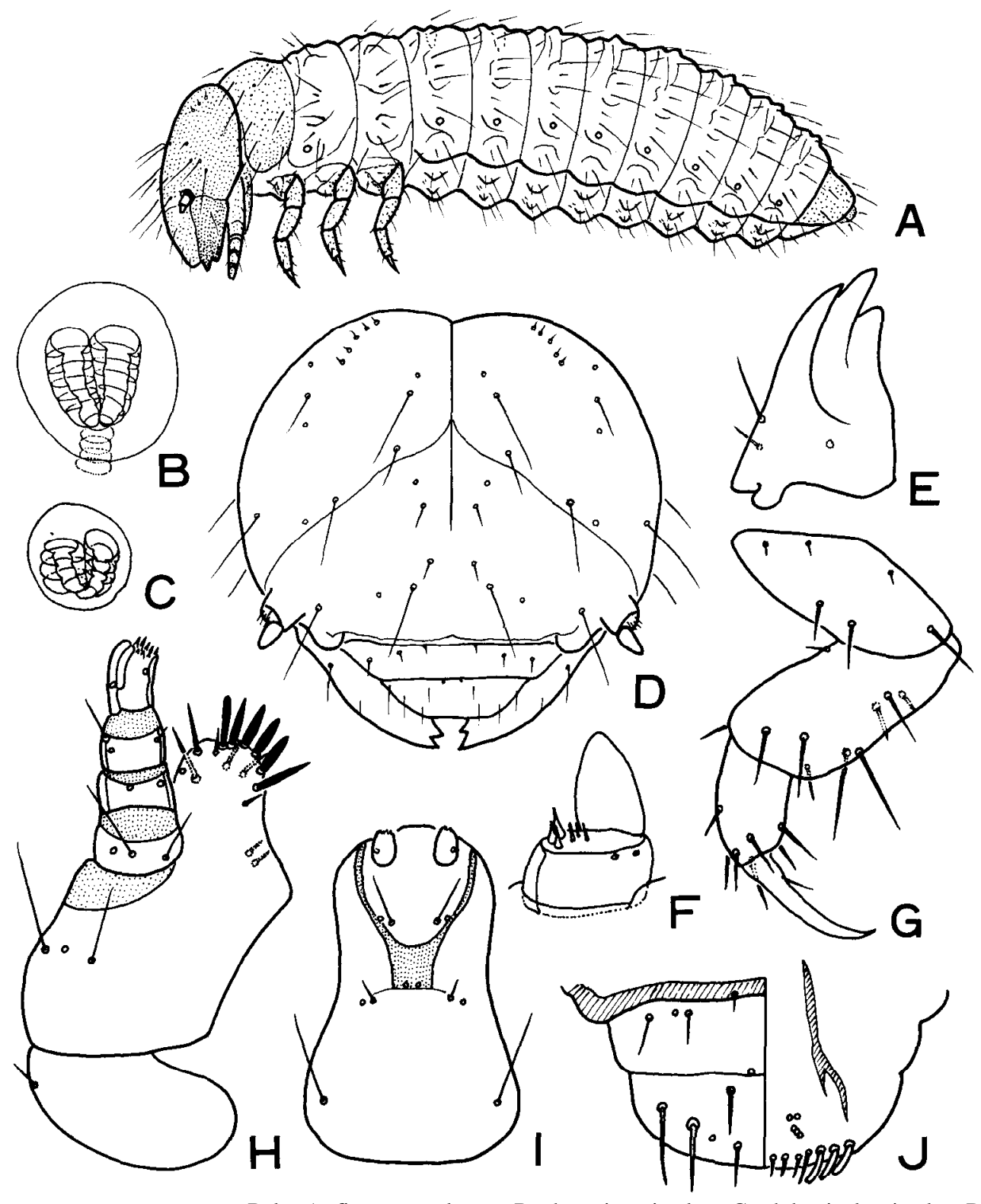

Fig. 1 Syneta adamsi Baly. A, first instar larva ; B, thoracic spiracle ; C, abdominal spiracle ; D, head ; E, mandible ; F, antenna ; G, leg ; H, maxilla ; I, labium ; J, clypeus, labrum and epipharynx.

ynx with two clusters of sensory pores, labral rods parallel-sided at basal half, forked anteriorly. Mandibles strongly sclerotized, with 3 teeth, without penicillus, each with one long seta, one minute basal seta, and one sensillum. Maxilla with cardo bears a small seta at side, stipes with 2 setae and a sensillum between them. Maxillary palpus I-segmented, segment 1 with one sensillum and 2 setae, segment 2 with 2 sensilla, segment 3 with one sensillum and 2 setae, of which inner one minute, 

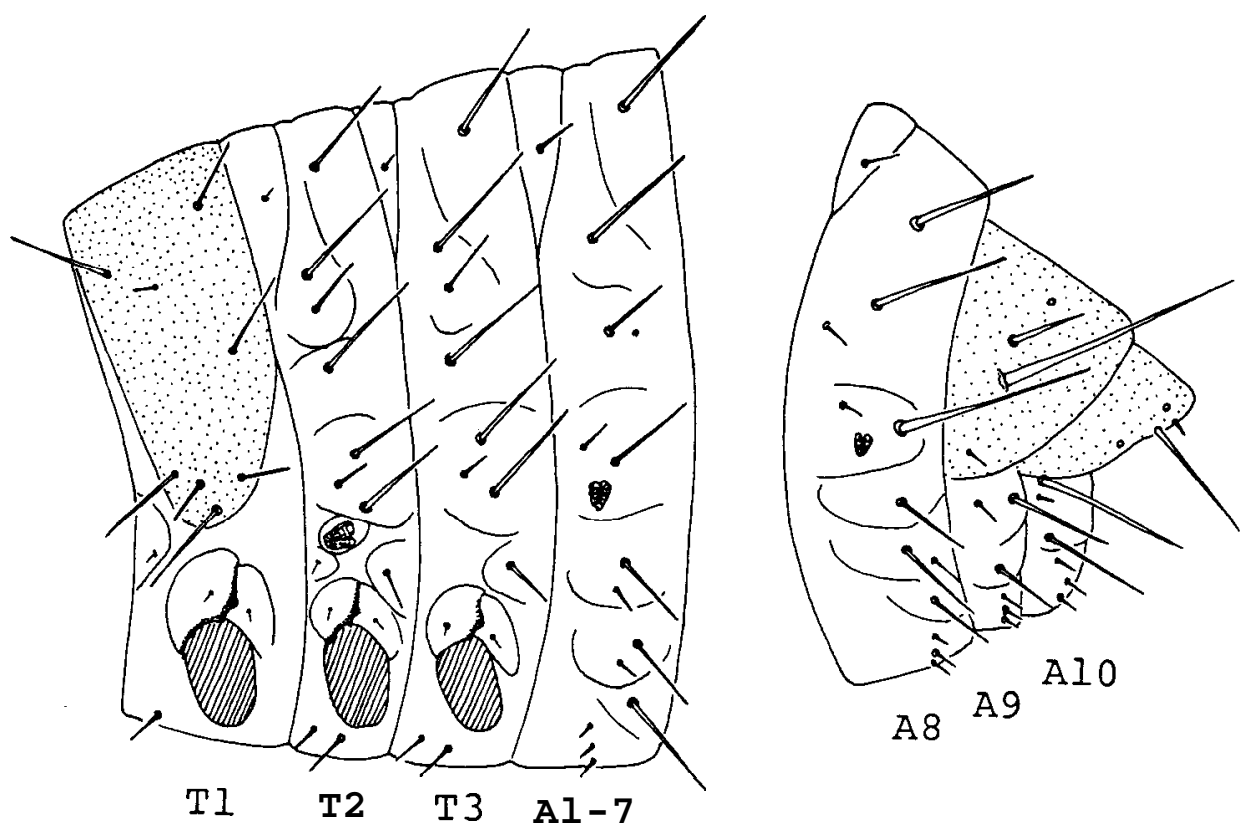

Fig. 2 Syneta adamsi Baly, chaetotaxy of first instar larva. T1, prothorax ; T2, mesothorax ; T3, metathorax ;A1-7, abdominal segments 1-7 ; A8, A9 and A10, abdominal segment 8, 9 and 10.

segment 4 with a process, which fit into a groove on the exterior side. Prementum with one pair of setae, one pair of sensilla at base and one pair of sensilla near the setae. Postmentum with one pair of long setae near postero-lateral corners, one pair of short setae and one pair of sensilla near anterior margin. Labial palpus 1-segmented.

Thorax. Pronotum slightly sclerotized, yellowish, with 8 pairs of setae, meso- and metanota each with one pair of minute prodorsal setae, 4 postdorsal setae and 3 laterodorsal setae ; episternum and epimeron each with a seta and divided by pleural suture, which strongly sclerotized and median parts spiniform ; prosternum with one and meso- and metasterna each with 2 setae. Legs uniform in structure and chaetotaxy ; coxa with 3 long setae on apical half, and with 3 minute setae near base, trochanter and femur completely fused, with 10 setae ; tibia with 7 setae ; tarsungulus acute, falciform, with one small seta a little before the base.

Abdomen. Typical abdominal segment with one pair of setae on prodorsum and 5 pairs of setae on postdorsum, of which fourth seta minute ; eighth segment also with 5 pairs of setae on postdorsum, 2 pairs of which located near posterior margin ; ninth and tenth terga sclerotized ; ninth tergum with 3 setae, of which median one largest and lateral one minute, and with a pair of sensilla near middle ; tenth tergum with 2 pairs of setae and two pairs of sensilla. Epipleuron of typical abdominal segment with one long and one short setae. Pleuron also with one long and one short setae. Sternum with one long seta on pedal area and 3 short setae on eusternum. Spiracles biforous, peritreme much smaller than air-tube ; mesothoracic spiracles much larger than those on abdomen, air-tubes directing posteriorly ; abdominal spiracles present on first to eighth segments, smaller in size, air-tubes directing dorsally.

Body length : $0.8 \mathrm{~mm}$.

Head width : $0.2 \mathrm{~mm}$. 
Material examined. Mt. Kujû, Ôita Pref., 27, V. 1988, adults collected and reared on leaves of Betula glob\&pica Shirai.

Discussion. The genus Syneta had usually been classified in the subfamily Orsodacninae until the estabilishment of the Synetinae by Edwards (1953). Crowson (1953) excluded Syneta from Orsodacninae and discussed in the evolutionary line from Orsodacninae to Galerucinae on the adult structures. Jolivet (1959) considered the direct origin of Synetinae from Orsodacninae on the wing venation. Chen (1964) placed Synetinae in his "Crioceridae", but he $(1973,86)$ revised his thinking and transferred it to "Chrysomelidae". Kurcheva $(1964,67)$ described the larva of Synetu betulae for the first time and placed Syneta in or close to Eumolpinae on the larval characters. Mann and Crowson (1981) proposed a phylogenetic system of the superfamily Chrysomeloidea and placed Synetinae in a monophyletic group with Eumolpinae, Galerucinae and Halticinae on the larval and adult characters.

Larva of Syneta adamsi is the same with that of S. betulae by comparing with the descriptions made by Kurcheva except for the following points :

Frons with 4 pairs of setae and a pair of short setae on fronto-clypeal suture near middle (only two pairs in S. betulae), anterior part of postmentum with a pair of short setae and one pair of sensilla (two pairs of setae in S. betulae), and endocarina half as long as frons ( $2 / 3$ as long as frons in $\mathrm{S}$. betulae).

The characteristics of Syneta are as follow:

Plesiomorphic states: Epicranial suture complete and distinct. Clypeus and labrum transverse and free. Maxillary palpi 4-segmented. Abdomen with eight pairs of functional spiracles. Body without sclerotized tubercles. Arrangements of setae and sensilla fundamental.

Apomorphic states : Antennae 1-segmented. Labral palpi 1-segmented. Stemmata absent. Trochanters and femora fused and their boundary absent. Abdominal segments 9 and 10 with sclerotized tergites. Spiracles biforous.

The arrangement of the setae and sensilla in Synetu adamsi is fundamentally similar to that of Curculionoidea, but has not been properly compared among taxa in Chrysomeloidea. The arrangements of the sensilla on the head and of the setae on the body were not mentioned by Kurcheva on S. betulae.

By the larval characters, Syneta is close to Eumolpinae in having the similar head capsule, mandibles, labial palpi, claws, spiracles and setal arrangement, but is characteristic by the sclerotized tergites of abdominal segment 9 and 10, one-segmented antennae, and fused trochanters and femora. Furthermore, the larvae of the Synetinae occupy the same ecological niche as those of Eumolpinae feeding on root in the soil.

\section{Acknowledgments}

I would like to express my cordial thanks to Prof. K. Morimoto of the Entomological Laboratory, Kyushu University, for guidance and reviewing the manuscript. My sincere thanks also due to Assoc. Prof. 0. Tadauchi for the suggestion and encouragement.

\section{$R$ eferences}

Chen, S., 1964. Evolution and classification of the chrysomelid beetles. Acta Ent. Sinica, 13 : 469483. (In Chinese with English summary)

- 1973. The classification of leaf beetles, Acta Ent. Sinica, $16: 47-56$. (In Chinese with English summary) 
- 1986. Fauna Sinica.Insecta,Coleoptera: Hispidue. 653 pp., 15 pls. Science Press, Beijing. (In Chinese)

Crowson, R. A., 1953. The classification of the families of British Coleoptera. Ent. month. Mug., LXXXIX : 181-198.

Edwards, J. G., 1953. Species of the genus Syneta of the world (Coleoptera: Chrysomelidae). Wasmann J. Biol., 11: 23-82.

Jolivet, P., 1957. Recherches sur l'aire des Chrysomeloidea (Coleoptera). Inst. r. Sci. nat. Belg., Mem. $2^{\mathrm{e}}$ ser., (51) : 1-180, 20 pls. ; (58) :1-152, 40 pls.

Kurcheva, G. F., 1964. Key for the identification of the genera of the subfamily Eumolpinae (including Syneta betulae F.). In Arnoldi, L. B. et al. (eds.) Key to soil dwelling insect larvae.919pp. USSR Acad. Sci. Press, Moscow. 522-524. (In Russian)

1967. Leaf beetle larvae of the subfamily Eumolpinae and Synetabetulae F. (Coleoptera, Chrysomelidae). Ent.Oboz., 46 :222-233. (In Russian). [Ent.Rev., 46:132-137].

LeSage, L., 1982. The immature stages of Exemacanadensis Pierce (Coleoptera, Chrysomelidae). Coleopt. Bull. $36:$ 318-327.

Mann, J. S. and R. A. Crowson, 1981. The systematic positions of Orsodacne Latr. and Syneta Lac. (Coleoptera, Chrysomelidae), in relation to characters of larvae, internal anatomy and tarsal vestiture. J. nut. Hist., 15 : 727-749. 